\title{
Measurement and modelling of photosynthetic response of pearl millet to soil phosphorus addition
}

\author{
W.A. Payne ${ }^{1}$, M.C. Drew ${ }^{2}$, L.R. Hossner ${ }^{3}$ and R.J. Lascano ${ }^{4}$ \\ ${ }^{1}$ ICRISAT Sahelian Center B.P. 12404, Niamey, Niger (via Paris) ${ }^{*},{ }^{2}$ Department of Horticultural Science, Texas A \\ and $M$ University, College Station, TX 77843, USA, ${ }^{3}$ Department of Soil and Crop Sciences, Texas $A$ and $M$ \\ University, College Station TX 77843, USA and ${ }^{4}$ Texas Agricultural Experiment Station, Rte 3, Box 219, Lubbock, \\ TX 79401-9757, USA
}

Received 30 November 1995. Accepted in revised form 13 March 1996

Key words: pearl millet, P.ennisetum glaucum (L.) R. Br., phosphorus, photosynthesis, modelling

\begin{abstract}
There have been no studies of the effects of soil P deficiency on pearl millet (Pennisetum glaucum (L.) R. Br.) photosynthesis, despite the fact that $\mathrm{P}$ deficiency is the major.constraint to pearl millet production in most regions of West Africa. Because current photosynthesis-based crop simulation models do not explicitly take into account $P$ deficiency effects on leaf photosynthesis, they cannot predict millet growth without extensive calibration. We studied the effects of soil addition on leaf $\mathrm{P}$ content, photosynthetic rate (A), and whole-plant dry matter production (DM) of non-water-stressed, $28 \mathrm{~d}$ pearl millet plants grown in pots containing $6.00 \mathrm{~kg}$ of a P-deficient soil. As soil $\mathrm{P}$ addition increased from 0 to $155.2 \mathrm{mg} \mathrm{P} \mathrm{kg}^{-1}$ soil, leaf $\mathrm{P}$ content increased from 0.65 to $7.0 \mathrm{~g} \mathrm{~kg}^{-1}$. Both A and $\mathrm{DM}$ had maximal values near $5.1 .7 \mathrm{mg} \mathrm{P} \mathrm{kg}{ }^{-1}$ soil, which corresponded to a leaf $\mathrm{P}$ content of $3.2 \mathrm{~g} \mathrm{~kg}^{-1}$. Within this range of soil $\mathrm{P}$ addition, the slope of A plotted against stomatal conductance $\left(\mathrm{g}_{\mathrm{s}}\right)$ tripled, and mean leaf internal $\mathrm{CO}_{2}$ concentration $\left(\left[\mathrm{CO}_{2}\right]_{\mathrm{i}}\right)$ decreased from 260 to $92 \mu \mathrm{L} \mathrm{L}^{-1}$, thus indicating that $\mathrm{P}$ deficiency limited $\mathrm{A}$ through metabolic dysfunction rather than stomatal regulation. Light response curves of $A$, which changed markedly with $P$ leaf content, were modelled as a single substrate, Michaelis-Menten reaction, using quantum flux as the substrate for each level of soil $\mathrm{P}$ addition. An Eadie-Hofstee plot of light response data revealed that both $\mathrm{K}_{\mathrm{M}}$, which is mathematically equivalent to quantum efficiency, and $V_{\max }$, which is the light-saturated rate of photosynthesis, increased sharply from leaf $P$ contents of 0.6 to $3 \mathrm{~g} \mathrm{~kg}^{-1}$, with peak values between 4 and $5 \mathrm{~g} \mathrm{P} \mathrm{kg}^{-1}$. Polynomial equations relating $\mathrm{K}_{\mathrm{M}}$ and $\mathrm{V}_{\max }$, to leaf $\mathrm{P}$ content offered a simple and attractive way of modelling photosynthetic light response for plants of different $\mathrm{P}$ status, but this approach is somewhat complicated by the decrease of leaf $\mathrm{P}$ content with ontogeny.
\end{abstract}

\section{Introduction}

Soil P-deficiency is considered to be the major constraint to pearl millet growth in the Sahel (e.g. Hafner et al., 1993). There have been several studies of the effects of $\mathrm{P}$ deprivation on photosynthesis of $\mathrm{C}_{3}$ plant species, but there have been only a few of $\mathrm{C}_{4}$ species, and most of these were of maize (Zea mays) (Bystrzejewska and Maleszewski, 1981; Jacob and Lawlor, 1991; Usuda and Shimogawara, 1991; Wong et al., 1985). Pearl millet has a different decarboxylating mechanism than maize (Edwards and Huber, 1981), and is generally considered to be more tolerant than maize to low nutrient availability and other environmental stresses. Other than a partial data set presented earlier related to whole-plant transpiration ratios $(\mathrm{kg}$ $\mathrm{DM} \mathrm{L}^{-1}$ transpiration) (Payne et al., 1992), we know of no studies of the effects of soil P availability on photosynthetic rates of pearl millet. Photosynthesis-based crop simulation models cannot therefore reliably predict pearl millet growth in $\mathrm{P}$ deficient soils without resorting to extensive calibration (e.g. Fechter et al.,

* FAX No: +227734329 
1991), which renders them of limited use for independent data sets.

In this paper we report the effects of soil $\mathrm{P}$ additions on pearl millet growth, leaf $\mathrm{P}$ content, assimilation rate (A), stomatal conductance $\left(\mathrm{g}_{\mathrm{s}}\right)$, and internal $\mathrm{CO}_{2}$ content $\left(\left[\mathrm{CO}_{2}\right]_{\mathrm{i}}\right)$. We then use simple Michaelis-Menten parameters to propose a model of light response of $\mathrm{A}$ for leaves of different $P$ status.

\section{Materials and methods}

The pearl millet variety ICTP 8203 (Rai et al., 1990) was grown in pots containing $6.00 \mathrm{~kg}$ of sandy soil from east Texas, which is classified in the US system as sandy, silicious, thermic Psammentic Paleustalf. The soil has a $\mathrm{pH}$ in water of 5.5 , a Bray I available $\mathrm{P}$ of $3 \mathrm{mg} \mathrm{kg}^{-1}$, an organic matter content of $0.2 \%$, and a cation exchange capacity of $5 \mathrm{cmol} \mathrm{kg}^{-1}$. It has a sand content of $0.92 \mathrm{~kg} \mathrm{~kg}^{-1}$, a clay content of $0.06 \mathrm{~kg} \mathrm{~kg}^{-1}$ and a bulk density of $1.63 \mathrm{Mg} \mathrm{m}^{-3}$. Its physical and chemical properties, including plant $P$ availability, are similar to those of pearl millet fields in West Africa.

Soil $\mathrm{P}$ additions were $0.00,0.023,0.062,0.116$, $0.310,0.621$ and $0.93 \mathrm{~g} \mathrm{P}$ per pot, each replicated four times. These additions correspond to absolute concentrations of $0.0,3.8,10.3,19.3,51.7,103.5$, and $155.2 \mathrm{mg} \mathrm{P} \mathrm{kg}^{-1}$ soil. Phosphorus was added as $\mathrm{Ea}\left(\mathrm{H}_{2} \mathrm{P} \Theta_{4}\right)_{2}-\mathrm{H}_{2} \Theta$-All-pots-reeeived-additionally -1.76 $\mathrm{g} \mathrm{K}_{2} \mathrm{SO}_{4}$ and $5.92 \mathrm{~g} \mathrm{NH}_{4} \mathrm{NO}_{3}$. All nutrients were added in powder form and mixed into dry soil before watering and planting.

Plants were grown under a fluorescent light bank for six days. Pots were then thinned to one plant, covered with plastic to prevent evaporation from the soil surface, and moved to a growth chamber. A combination of fluorescent and incandescent lights was used to maintain photosynthetic photon flux density (PPFD) within the growth chamber at $500 \mu \mathrm{mol} \mathrm{m}{ }^{-2} \mathrm{~s}^{-1}$. Temperatures were $32^{\circ} \mathrm{C}$ during a $14 \mathrm{~h}$ day and $21^{\circ} \mathrm{C}$ during a $10 \mathrm{~h}$ night. Electrical fans were used to generate a windspeed of approximately $0.5 \mathrm{~m} \mathrm{~s}^{-1}$. Atmospheric water vapour pressure was approximately $2.1 \mathrm{kPa}$, and ambient $\mathrm{CO}_{2}$ concentration was approximateiy $360 \mu \mathrm{L}$ $\mathrm{L}^{-1}$.

Initial average soil water content was $0.16 \mathrm{~m}^{3} \mathrm{~m}^{-3}$, which approximates field capacity in this sandy soil. Plants were watered daily to compensate for daily transpiration rate, which was determined from weighing every two or three days. Pots were randomly repositioned in the growth chamber after each weighing.
At 28 days after planting (DAP), A was measured on the youngest, fully expanded leaf of each plant at $500 \mu \mathrm{mol} \mathrm{m} \mathrm{m}^{-2} \mathrm{~s}^{-1}$ PPFD. Leaf gas exchange was measured using an ADC LCA-2 infrared gs analyzer and PLC(N) leaf chamber (The Analytical Development Company, Hoddesdon, Herts, England). ${ }^{1}$ At 29 DAP, A was measured in the same manner at PPFD of 1000,1500 , and $2000 \mu \mathrm{mol} \mathrm{m}^{-2} \mathrm{~s}^{-1}$, using a rheostatcontrolled light apparatus. A circulating water bath was kept between the light source and leaf to reduce infrared radiation and leaf temperature fluctuations. Measurements of $A$ were not taken until leaves had reached a new steady-state gas exchange rate, which required 20 to 30 minutes. Gas exchange measurements were made on only two plants at PPFD, of 1000,1500 and $2000 \mu \mathrm{mol} \mathrm{m}{ }^{-2} \mathrm{~s}^{-1}$. No reading was obtained for the $51.7 \mathrm{mg} \mathrm{P} \mathrm{kg}^{-1}$ soil treatment at $2000 \mu \mathrm{mol} \mathrm{m}^{-2} \mathrm{~s}^{-1}$ due to equipment failure.

The ADC flow rate was held constant at 4800 $\pm 100 \mathrm{~mm}^{-3} \mathrm{~s}^{-1}$. Leaf boundary layer conductance, determined from wetted filter paper in the cuvette, was $5 \mathrm{~mol} \mathrm{~m}^{-2} \mathrm{~s}^{-1}$. Leaf internal $\mathrm{CO}_{2}$ concentration, $\left[\mathrm{CO}_{2}\right]_{i}, \mathrm{~A}$, and $\mathrm{g}_{\mathrm{s}}$ were calculated using equations programmed in the ADC.

At 29 DAP, leaf segments on which gas exchange measurements were made were removed and assayed for chlorophyll $a$ and $b$ using the method of Arnon (1949). The remaining leaves were dried at 70 ${ }^{\circ} \mathrm{C}$-weighed and ground. A sample of the ground leaves was acid digested, and assayed on a Technicon autoanalyser ${ }^{1}$ for total $\mathrm{P}$ using the molybdate blue method, and for total $\mathrm{N}$ using the salicylatehypochlorite-nitroprusside method (Technicon, 1976). Roots were washed from the soil, then dried and weighed with shoots.

Statistical analyses of plant dry matter partitions, shoot:root ratios, total $\mathrm{N}$ and $\mathrm{P}$ concentrations, leaf segment chlorophyll concentration, and internal $\mathrm{CO}_{2}$ concentraton were made using the MGLH module of SYSTAT (Wilkinson, 1987). Because DM data were heteroscedastic, i.e. variances increased with dry mass, data were log-weighted for mean separation. No data transformations were for shoot:root ratios. Tukey's hsd test was used for all mean separations. Linear regression equations were fitted to $\mathrm{A}$ and $\mathrm{g}_{\mathrm{s}}$ data for plants of each $P$ treatment using SYSTAT.

Light response data for each level of soil $P$ addiitions were plotted in an Eadie-Hofstee plot (Fersht, 1985), using PPFD as the substrate for A, to obtain

\footnotetext{
1 Mention of tradenames does not constitute an endorsement.
} 
Table 1. Pearl millet dry matter production and shoot:root ratios as affected by soiladded $P$. Values represent means determined from four pots

\begin{tabular}{cccccc}
\hline $\begin{array}{c}\text { Soil-added P } \\
\left(\mathrm{mg} \mathrm{kg}^{-1}\right)\end{array}$ & Roots $(\mathrm{g})$ & Leaves $(\mathrm{g})$ & Stems $(\mathrm{g})$ & $\begin{array}{c}\text { Shoot:Root } \\
\left(\mathrm{g} \mathrm{g}^{-1}\right)\end{array}$ & Total $(\mathrm{g})$ \\
\hline 0 & $0.25 \mathrm{a}$ & $0.08 \mathrm{a}$ & $0.02 \mathrm{a}$ & $0.49 \mathrm{a}$ & $0.36 \mathrm{a}$ \\
3.8 & $1.50 \mathrm{~b}$ & $1.14 \mathrm{~b}$ & $0.54 \mathrm{~b}$ & $1.03 \mathrm{ab}$ & $3.19 \mathrm{~b}$ \\
10.3 & $3.11 \mathrm{bc}$ & $2.61 \mathrm{bc}$ & $1.57 \mathrm{c}$ & $1.35 \mathrm{ab}$ & $7.29 \mathrm{bc}$ \\
19.3 & $5.11 \mathrm{~cd}$ & $4.13 \mathrm{~cd}$ & $2.56 \mathrm{~cd}$ & $1.48 \mathrm{~b}$ & $11.80 \mathrm{~cd}$ \\
51.7 & $10.05 \mathrm{~d}$ & $9.44 \mathrm{~d}$ & $5.49 \mathrm{~d}$ & $1.53 \mathrm{~b}$ & $24.99 \mathrm{~d}$ \\
103.5 & $5.88 \mathrm{~cd}$ & $4.85 \mathrm{~cd}$ & $3.26 \mathrm{~cd}$ & $1.51 \mathrm{~b}$ & $13.98 \mathrm{~cd}$ \\
155.2 & $6.49 \mathrm{~cd}$ & $7.01 \mathrm{~cd}$ & $4.55 \mathrm{~cd}$ & $1.91 \mathrm{~b}$ & $18.05 \mathrm{~cd}$ \\
\hline
\end{tabular}

Means within the same column followed by the same letter or letters are not significantly different at $p=0.05$ according to Tukey's hsd test.

estimates of the Michaelis-Menten parameters $K_{M}$ and $\mathrm{V}_{\max }$. Polynomial equations were fitted to the response of $K_{M}$ and $V_{\max }$ to leaf $P$ content using SYSTAT'S NONLIN module.

\section{Results and discussion}

\section{Dry matter production and nutrient accumulation}

Root, stem, leaf, shoot and whole-plant DM increased greatly with soil added $\mathrm{P}$ up to $51.7 \mathrm{mg} \mathrm{P} \mathrm{kg}^{-1}$ soil. Although there was an apparent decrease in DM at soil $\mathrm{P}$ additions greater than $51.7 \mathrm{mg} \mathrm{P} \mathrm{kg}^{-1}$ soil, there were no statistically significant differences among soil $\mathrm{P}$ additions greater than $19.3 \mathrm{mg} \mathrm{P} \mathrm{kg}^{-1}$ soil (Table 1). As soil added $P$ increased from 0 to $19.3 \mathrm{mg} \mathrm{P} \mathrm{kg}^{-1}$ soil, mean root DM increased $220 \%$, mean leaf DM increased $570 \%$, stem DM increased $1230 \%$, and shoot:root ratios tripled.

Leaf $\mathrm{P}$ content nearly doubled as soil $\mathrm{P}$ addition increased from 0 to $3.8 \mathrm{mg} \mathrm{P} \mathrm{kg}^{-1}$ soil (Table 2). Although leaf $\mathrm{P}$ content continued to increase with greater soil $\mathrm{P}$ addition, increases were less pronounced at the greatest $\mathrm{P}$ additions. For example, as soil $\mathrm{P}$ addition increased from 103.5 to $155.2 \mathrm{mg} \mathrm{P} \mathrm{kg}^{-1}$ soil, leaf $\mathrm{P}$ content only increased by $0.50 \mathrm{~g} \mathrm{~kg}^{-1}$. Leaf chlorophyll concentration increased slightly with decreasing $P$ availability (Table 2 ), which is consistent with other studies of $\mathrm{P}$ deciency in plants (Terry and Ulrich, 1973). Leaf nitrogen concentration was unaffected by $P$ treatment (Table 2 ).
Table 2. Phosphorus and nitrogen content of pearl millet leaves, and leaf chlorophyll content of leaf segments measured for gas exchange

\begin{tabular}{cccc}
\hline $\begin{array}{l}\text { Soil } \\
\text { Added P } \\
\left(\mathrm{mg} \mathrm{kg}^{-1}\right)\end{array}$ & $\begin{array}{c}\text { Leaf } \\
\text { P content } \\
\left(\mathrm{g} \mathrm{kg}^{-1}\right)\end{array}$ & $\begin{array}{c}\text { Leaf } \\
\text { N content } \\
\left(\mathrm{g} \mathrm{kg}^{-1}\right)\end{array}$ & $\begin{array}{c}\text { Chlorophyll } \\
\text { content } \\
\left(\mu \mathrm{g} \mathrm{cm}^{-2}\right)\end{array}$ \\
\hline 0 & $0.65 \mathrm{a}$ & $55.5 \mathrm{a}$ & $14.7 \mathrm{a}$ \\
3.8 & $1.18 \mathrm{a}$ & $57.3 \mathrm{a}$ & $12.1 \mathrm{a}$ \\
10.3 & $1.45 \mathrm{a}$ & $50.3 \mathrm{a}$ & $11.0 \mathrm{a}$ \\
19.3 & $1.95 \mathrm{ab}$ & $55.0 \mathrm{a}$ & $7.3 \mathrm{~b}$ \\
51.7 & $3.20 \mathrm{~b}$ & $47.0 \mathrm{a}$ & $7.2 \mathrm{~b}$ \\
103.5 & $6.50 \mathrm{c}$ & $54.0 \mathrm{a}$ & $7.7 \mathrm{~b}$ \\
155.2 & $7.00 \mathrm{c}$ & $49.7 \mathrm{a}$ & $6.4 \mathrm{~b}$ \\
\hline
\end{tabular}

Means within the same column followed by the same letter or letters are not significantly different at $p=0.10$ according to Tukey's hsd test.

\section{Leaf gas exchange}

Leaf $A$ increased as soil $P$ addition increased from 0 to $155.2 \mathrm{mg} \mathrm{P} \mathrm{kg}^{-1}$ soil (Figure 1) then slightly decreased. However, the slight decline in $\mathrm{A}$ with soil $\mathrm{P}$ additions greater than $51.7 \mathrm{mg} \mathrm{P} \mathrm{kg}^{-1}$ soil was not statistically significant, similar to $\mathrm{DM}$ response to $\mathrm{P}$ additon (Table 1). Soil $P$ additon of $51.7 \mathrm{mg} \mathrm{P} \mathrm{kg}^{-1}$ soil corresponded to a leaf $P$ content of about $3.2 \mathrm{~g} \mathrm{P} \mathrm{kg}^{-1}$ (Table 2). Differences in A among treatments of soil added P were more apparent at higher PPFD. A was lightsaturated at much lower PPFD for low $\mathrm{P}$ treatments compared to higher $\mathrm{P}$ treatments. The curves in Figure 1 are qualitatively similar to those reported for the ratio of $\mathrm{CO}_{2}$ to $\mathrm{H}_{2} \mathrm{O}$ flux by Payne et al. (1992). There is no clear distinction among light response curves in Figure 1 for plants receiving $\geq 51.7 \mathrm{mg} \mathrm{P} \mathrm{kg}^{-1}$ soil, but this may be due to the relatively low PPFD in the 


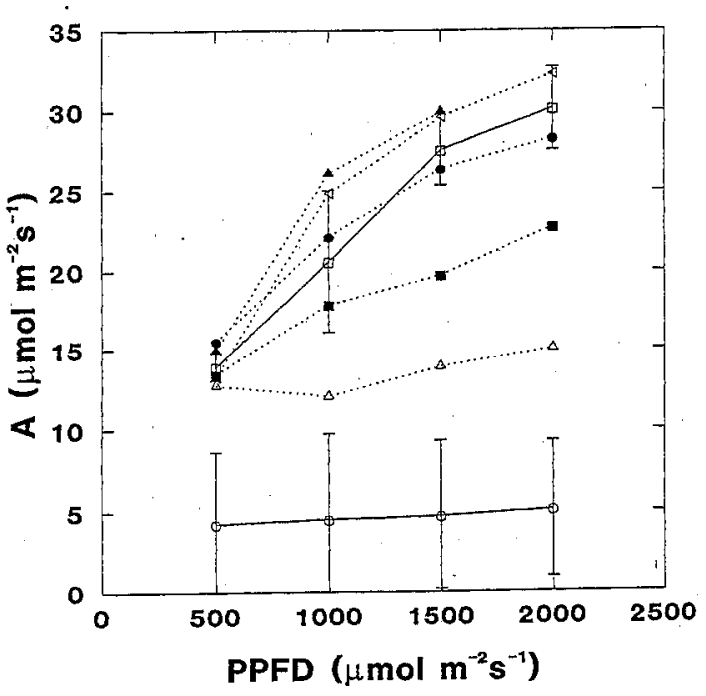

Figure l. Photosynthetic flux density (A) response to photosynthetic photon flux density (PPFD). Bars represent \pm 1 S.E., and are presented for the lowest and highest $P$ treatments only. Phosphorus treatments were: $0(\bigcirc), 3.8(\Delta), 10.3(\mathbb{G}), 19.3(\mathbf{O}), 51.7(\mathbf{\Delta})$, $103.5(\varangle)$ and $155.2(\square) \mathrm{mg} \mathrm{P} \mathrm{kg}^{-1}$ soil.

growth chamber, and subsequent poor acclimation to greater light intensity. As soil $\mathrm{P}$ additions increased from 0 to $155.2 \mathrm{mg} \mathrm{P} \mathrm{kg}^{-1}$ soil, the slopes of linear models fitted to $\mathrm{A}$ as a function of $\mathrm{g}_{s}$ increased over three fold, as shown for four of the P treatments in Figure 2. This slope remained unchanged in P-deficient soybeans (Lauer et al., 1989) and cotton and maize (Wong et al., 1985), but decreased in P-deficient cotton (Ackerson, 1985) and N-deficient wheat (Heitholt et al., 1991). Radoglou et al. (1982) found that this slope increased for Phaseolus vulgaris plants grown under conditions of nutrient stress at elevated $\mathrm{CO}_{2}$ levels.

Inconsistent reports of the response of ratio $\mathrm{A} / \mathrm{g}_{\mathrm{s}}$ could be related to the severity of nutrient deficiency. For example, Wong et al. (1985) grew plants in sterilized garden soil, and Radoglou et al: (1992) used compost. Both are probably much higher in soil $\mathrm{P}$ availability than the sandy soil used in this study. It could also depend upon plant species. For example, Goudriaan and Van Keulen (1979) found that maize maintained stomatal control under $\mathrm{N}$ stress, whereas sunflower (Helianthus annuus) did not. The reduction of $\mathrm{A} / \mathrm{g}_{\mathrm{s}}$ caused by $\mathrm{P}$ deficiency shown in Figure 2 is consistent with the well established phenomenon of reduced transpiration ratios of whole plants when grown under conditions of nutrient stress (Briggs and Shantz, 1913; de Wit, 1958; Payne et al., 1992). Because mean

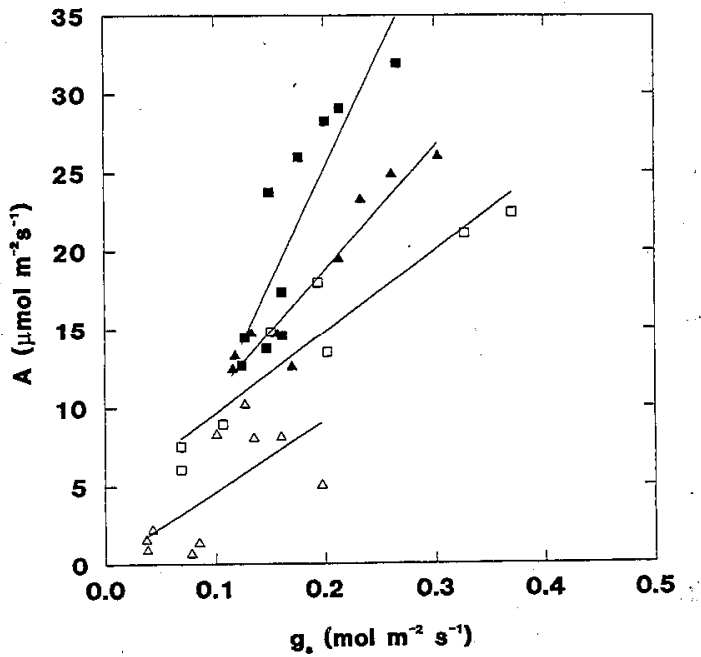

Figure 2. Photosynthetic flux density (A) and stomatal conductance to water vapor $\left(\mathrm{g}_{\mathrm{s}}\right)$, as affected by soil added $\mathrm{P}$ for pearl millet. Slopes of linear models were: $45.6(\mathrm{SE}=17.8)$ for $0 \mathrm{mg} \mathrm{P} \mathrm{kg}^{-1}$ soil $(\triangle), 53.5(\mathrm{SE}=5.9)$ for $3.8 \mathrm{mg} \mathrm{P} \mathrm{kg}^{-1}$ soil $(\square), 79.1$ (SE=9.8) for $19.3 \mathrm{mg} \mathrm{P} \mathrm{kg}^{-1}$ soil $(\boldsymbol{\Lambda})$, and $147.6(\mathrm{SE}=29.0)$ for $155.2 \mathrm{mg}$ added $\mathrm{P} \mathrm{kg}^{-1}$ soil (回).

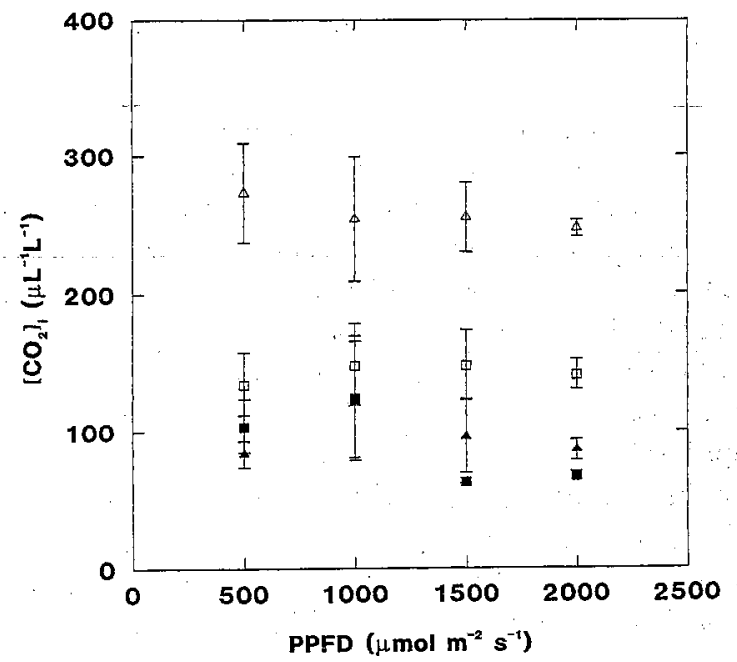

Figure 3. Internal $\mathrm{CO}_{2}$.concentration of pearl millet leaves as affected by soil added P. Points at 500 PPFD represent means of four replicates. Other points are means of two replicates. Bars represent \pm 1 S.E. Soil P treatments were: $0(\Delta), 3.8(\square), 19.3(\boldsymbol{\Delta})$, and 155.2 (1) $\mathrm{mg}$ added $\mathrm{P} \mathrm{kg}^{-1}$ soil.

$\left[\mathrm{CO}_{2}\right]_{\mathrm{i}}$ increased at lower $\mathrm{P}$ levels (Figure 3) while A decreased, A was limited in this experiment by metabolic dysfunction, and not by stomatal control (Farquhar and Sharkey, 1982). The lack of stomatal control would explain at least in part the reduced ratio of $\mathrm{CO}_{2}$ to $\mathrm{H}_{2} \mathrm{O}$ flux and reduced transpiration ratios. 


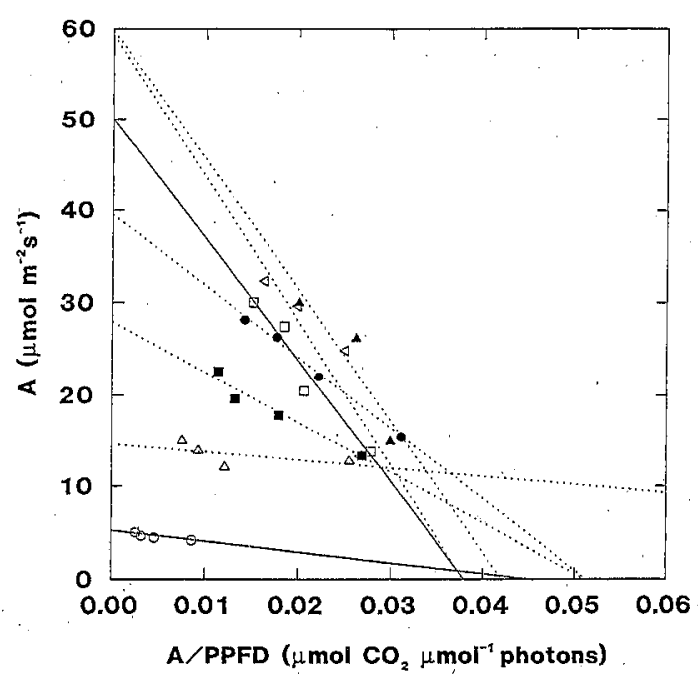

Figure 4. Eadie-Hofstee plot of photosynthesis (A) plotted against A divided by photosynthetic photon flux (PPFD) for pearl millet as affected by soil $P$ addition. Phosphorus treatments were: $0(\bigcirc), 3.8$ $(\triangle), 10.3(\mathbf{\square}), 19.3(\bullet), 51.7(\mathbf{\Delta}), 103.5(\triangleleft)$ and $155.2(\square) \mathrm{mg}$ added $\mathrm{P} \mathrm{kg}^{-1}$ soil.

\section{Model construction}

Photosynthetic light response data for each leaf $\mathrm{P}$ content were redrawn in the Eadie-Hofstee plot of Figure 4. For all soil added $\mathrm{P}$ levels save $3.8 \mathrm{mg} \mathrm{P} \mathrm{kg}^{-1}$ soil (corresponding to $1.18 \mathrm{~g} \mathrm{P} \mathrm{kg}^{-1}$ leaf), there was a good linear relation between $A$ and $A / P P F D$, consistent with single substrate Michaelis-Menten kinetics. In Eadie-Hofstee plots, the y-intercept is equal to $V_{\max }$, or the substrate-saturated rate of an enzyme-mediated reaction, and the slope to $-\mathrm{K}_{\mathrm{m}}$, the Michaelis-Menten apparent dissociation constant. We interpret $\mathrm{V}_{\max }$ to be the rate of photosynthesis at light-saturation, and $\mathrm{K}_{\mathrm{M}}$ to be equivalent to quantum efficiency. Both $V_{\max }$ and $\mathrm{K}_{\mathrm{M}}$ increased greatly as leaf $\mathrm{P}$ content increased from 0.7 to $3 \mathrm{~g} \mathrm{P} \mathrm{kg}^{-1}$ (Figure 5). It is difficult to say from our data whether they remained the same or had maxima between 3 and $7 \mathrm{~g} \mathrm{P} \mathrm{kg}^{-1}$ leaf. Because both $\mathrm{DM}$ and $\mathrm{A}$ tended to have maxima at about $51.7 \mathrm{mg} \mathrm{P}$ $\mathrm{kg}^{-1}$ soil (corresponding to $3.2 \mathrm{mg} \mathrm{P} \mathrm{kg}^{-1}$ leaf), we fitted the polynomials:

$$
\mathrm{K}_{\mathrm{M}}=-1536+1302 \mathrm{x}-127.3 \mathrm{x}^{2}+1549 \mathrm{e}^{-\mathrm{x}}
$$

to the $\mathrm{K}_{\mathrm{M}}$ data $\left(\mathrm{R}^{2}=0.93\right)$, and

$$
\ln V_{\max }=0.173-0.88 x+3.76 \sqrt{x}
$$

to the $\mathrm{V}_{\max }$ data $\left(\mathrm{R}^{2}=0.89\right)$. In both equations, there are maxima between $x$ values of 3 and 7 , where $x$ is leaf $P$ content. Obviously it would be unwise to extrapolate to $V_{\max }$ and $K_{M}$ values at leaf $P$ contents greater than $7 \mathrm{~g} \mathrm{P} \mathrm{kg}^{-1}$. Both equations can be substituted into the equation

$$
\mathrm{A}=\left(\mathrm{V}_{\max } \cdot \mathrm{PPFD}\right) /\left(\mathrm{PPFD}+\mathrm{K}_{\mathrm{M}}\right),
$$

which is a rearrangement of the equation used in the Eadie-Hofstee plot (Figure 4).

Equation (3) permits an attractively simple way to model photosynthetic light response of pearl millet leaves as a function of their P status, as illustrated in Figure 6 for four levels of PPFD. An interesting prediction of the model which should be tested experimentally is that optimal leaf $P$ content increases with quantum flux.

For such a model to calculate light interception, leaf growth must be correctly simulated. Translating pearl millet $\mathrm{A}$ into leaf DM for individual leaves would be facilitated using the specific leaf area (SLA) equation developed by Payne et al. (1991),

$$
\mathrm{SLA}=176.7 \mathrm{M}^{-0.216}
$$

where $M$ is leaf dry mass ( $\mathrm{g}$ ), and SLA is in units of $\mathrm{cm}^{-2} \mathrm{~g}^{-1}$. This equation appeared to be valid for pearl millet plants irrespective of age, water stress, and phosphate stress. Stressed plants tended to have smaller leaves, but their SLA increased according to Equation (4) as their mass decreased.

One of the earliest symptoms of P-deficiency within plants is a decline in free orthophosphate ion concentration $\left(\mathrm{P}_{\mathrm{i}}\right)$ within the cytoplasm of the leaf mesophyll. This quickly limits photosynthetic metabolism because the export of triose phosphates from the chloroplast (via the phosphate translocator) is driven by the simultaneous import of $P_{i}$ (Sivak and Walker, 1985). Thus it would be preferable to model $A$ as a function of $P_{i}$. Unfortunately, relating $P_{i}$ to leaf $P$ content is not easily done. Furthermore, most laboratories can measure leaf $\mathrm{P}$ content of field-grown plants, whereas few can measure cytopasmic concentration of $\mathrm{P}_{i}$.

One complication with the modelling approach illustrated in Figure 6 is that leaf P content of pearl millet decreases with ontogey (Payne et al., 1995). Unless a more mechanistic way could be found to model this decrease, then Equation 3, which was developed for $28 \mathrm{~d}$ plants, might have to be replaced by a series of empirical curves to model photosynthesis throughout the growing cycle.

Finally, this study did not take into account the effects of water stress on leaf photosynthesis and stomatal conductance, despite the fact that water stress 

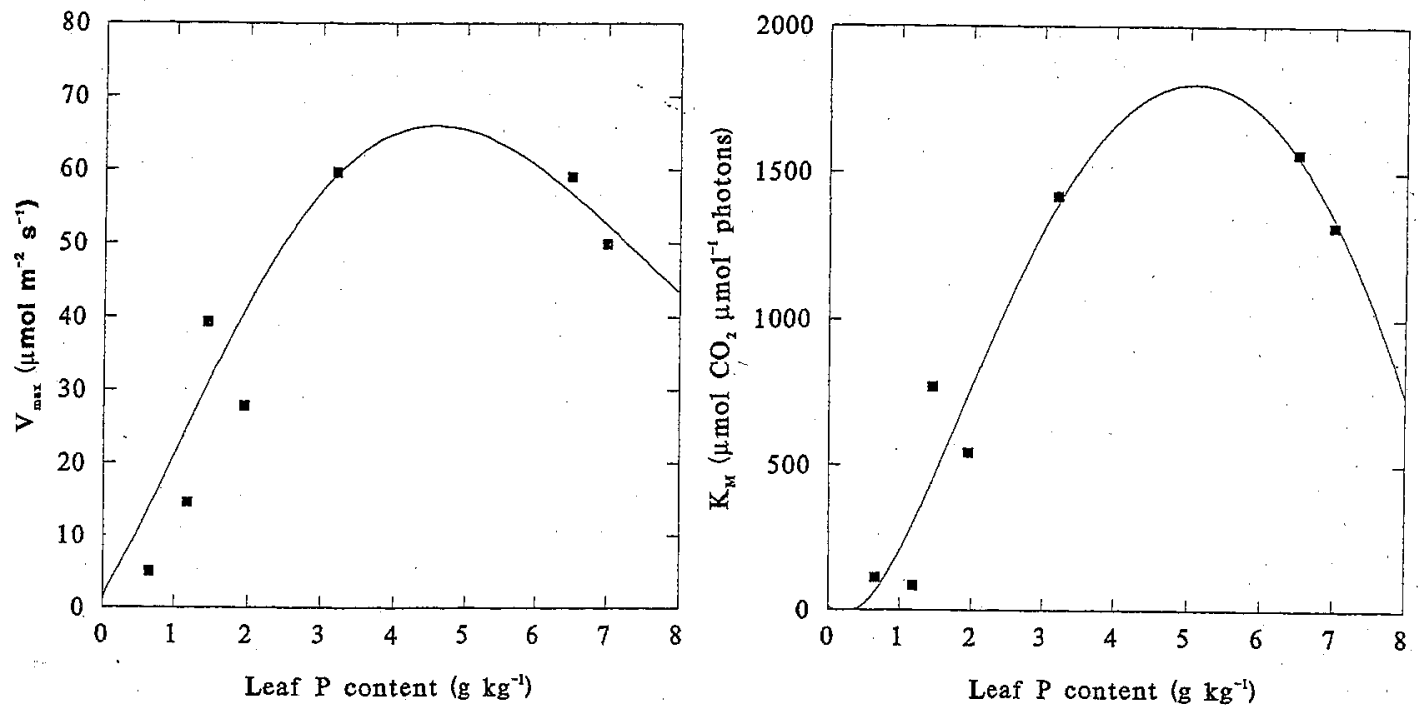

Figure 5. Michaelis-Menten parameters $\mathrm{V}_{\max }$ and $\mathrm{K}_{\mathrm{M}}$ as a function of pearl millet leaf $\mathrm{P}$ content.

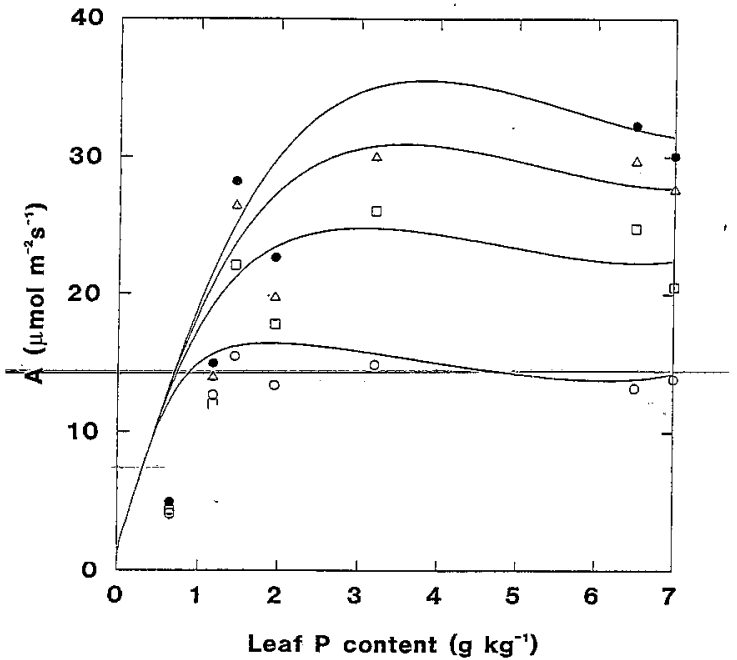

Figure 6. Modelled response of pearl millet leaf photosynthesis (A) to four levels of photosynthetic photon flux (PPFD). The four levels of PFFD were $500(\bigcirc), 1000(\square), 1500(\triangle)$ and $2000(\bullet) \mu \mathrm{mol}$ $\mathrm{m}^{-2} \mathrm{~s}^{-1}$.

occurs commonly under field conditions. Current studies are underway to incorporate water and $\mathrm{P}$ stress into photosynthesis models designed for field conditions.

\section{References}

Ackerson R C 1985 Osmoregulation in cotton in response to water stress. III. The effects of phosphorus fertility. Plant Physiol. 77, 309-312.
Amon D I 1949 Copper enzyme in isolated chloroplasts. Polyphenoloxidase in Beta vulgaris. Plant Physiol. 24, 1-15.

Briggs L J and Shantz H L 1913 The water requirement of plants: II. A review of the literature. USDA Bureau of Plant Industry Bulletin 285. USDA, Washington, DC, USA.

Bystrzejewska G and Maleszewski S 1981 Phosphorus nutrition as a factor influencing photosynthesis in maize plants. I. The effect of phosphorus level on light enhanced dark $\mathrm{CO}_{2}$ fixation in leaves. Z. Pflanzenphysiol. Bodenkd. 101, 249-255.

De Wit C T 1958 Transpiration and crop yield. Verslagen Land--bouwkundige Onderzoekingen 64(6). Institute of Biology and Chemical Research on Field Crops and Herbage, Wageningen, The Netherlands.

Edwards GE and Huber S C 1981 The $\mathrm{C}_{4}$ pathway. In The Biochemistry of Plants. A Comprehensive Treatise, Vol. 8 of Photosynthesis. Eds. P K Stumpf and E E Conn. pp 237-281. Academic Press, New York, USA.

Farquhar G D and Sharkey T D 1982 Stomatal conductance and photosynthesis. Annu. Rev. Plant Physiol. 33, 317-345.

Fechter J, Allison B E, Sivakumar M V K, Van Der Ploeg R R and Bley J 1991 An evaluaton of the SWATRER and CERESMillet models for southwest Niger. In Soil Water Balance in the Sudano-Sahelian Zone. Proceedings of the Niamey Workshop, February 1991. Eds. M V K Sivakumar, J S Wallace, C Renard and C Giroux. IAHS Publ. no. 199, pp 505-513. Institute of Hydrology, Wallingford, UK.

Fersht A 1985 Enzyme Structure and Mechanism. W H Freeman and Company, New York, USA. 475 p.

Goudriaan J and van Keulen H 1979 The direct and indirect effects of nitrogen shortage on photosynthesis and transpiration in maize and sunflower. Neth. J. Agric. Sci. 27, 227-234.

Hafner H, George E, Baiono A and Marschner H 1993 Effect of crop residues on root growth and phosphorus acquisition of pearl millet in an acid sandy soil in Niger. Plant and Soil 150, 117-127.

Heitholt J J, Johnson R C and Ferris D M 1991 Stomatal limitation to carbon dioxide assimilation in nitrogen- and drought-stressed wheat. Crop Sci. 31, 135-139. 
Jacob J and Lawlor D W 1991 Stomatal and mesophyll limitations of photosynthesis in phosphate deficient sunflower, maize and wheat plants. J. Exp. Bot. 42, 1003-1011.

Lauer M J, Pallardy S G, Blevins D G and Randall D 1989 Whole leaf carbon exchange characteristics of phosphate deficient soybeans (Glycine max L.). Plant Physol. 91, 848-854.

Payne W A, Hossner L R, Onken A B and Wendt C W 1995 Nitrogen and phosphorus uptake in pearl millet and its relation to nutrientand water-use efficiency. Agron J. 87, 425-431.

Payne W A, Drew M C, Hossner L R, Lascano R J, Onken A B and Wendt C W 1992 Soil P availability and pearl millet water-use efficiency. Crop Sci. 32, 1010-1015.

Payne W A, Wendt C W Wendt, Hossner L R and Gates C E 1991 Estimating pearl millet leaf area and specific leaf area. Agron. J. $83,937-941$.

Radoglou K M, Aphalo P and Jarvis P G 1992 Response of photosynthesis, stomatal conductance and water use efficiency to elevated $\mathrm{CO}_{2}$ and nutrient supply in acclimated seedlings of Phaseolus vulgaris L. Ann. Bot. 70, 257-264.

Rai K N, Kumar A N, Andrews D J, Rao A S, Raj A G B and Witcombe J R 1990 Registration of 'ICTP 8203' pearl millet. Crop Sci. 30, 959.
Sivak M N and Walker D A 1985 Photosynthesis in vivo can be limited by phosphate supply. New Phytol. 102, 499-512.

Technicon Industrial System 1976 Individual/simultaneous determination of nitrogen and/or phosphorus in $\mathrm{BD}$ acid digests. Industrial Method No. 334-74/W B, 7 p. Technicon Industrial Systems, Tarrytown, NY, USA.

Terry. N and Ulrich A 1973 Effects of phosphorus deficiency on the photosynthesis and respiration of leaves of sugar beet. Plant Physiol. 51, 42-47.

Usuda $\mathrm{H}$ and Shimogawara K 1991 Phosphate deficiency in maize. I. Leaf phosphate status, growth, photosynthesis and carbon partitioning. Plant Cell Physiol. 32, 497-504.

Wilkinson L 1987 SYSTAT: The system for statistics. SYSTAT Inc., Evanston, IL, USA.

Wong S C, Cowan I R and Farquhar G D 1985 Leaf conductance in relation to rate of $\mathrm{CO}_{2}$ assimilation. I. Influence of nitrogen nutrition, phosphorus nutrition, photon flux density, and ambient partial pressure of $\mathrm{CO}_{2}$ during ontogeny. Plant Physiol. $78,821-825$.

Section editor: H Marschner (deceased 21 September 1996) 